\title{
SAKRAMENT POKUTY I POJEDNANIA W MISTAGOGIl LITURGICZNEJ
}

Streszczenie. Polscy katolicy zasadniczo przystępują do sakramentu pokuty kilka razy w roku przed ważnymi uroczystościami, a sporo wiernych nadal spowiada się co miesiąc przed pierwszym piątkiem miesiąca. Problemem jest mniej lub bardziej rutynowe podejście przez nich do tego sakramentu. Celowe więc wydaje się spojrzenie na sakrament Bożego miłosierdzia z perspektywy jego obecności w mistagogii liturgicznej sprawowanej w Kościele. Artykuł przypomina założenia współczesnej mistagogii liturgicznej. Jednak jego główna część jest próbą przybliżenia czytelnikowi treści teologicznych odnowionej liturgii pokuty i pojednania, w których akcent położony jest na trynitarnym wymiarze Bożego miłosierdzia, eklezjalnym charakterze liturgii omawianego sakramentu oraz personalistycznym jej aspekcie. Istotnym dopełnieniem jest pokazanie, że sakrament pokuty i pojednania jest zawsze sprawowaniem liturgii Kościoła.

Dlatego ma on być dla wierzącego w Chrystusa nie czymś, czego trzeba się bać, ale środkiem umożliwiającym jednanie się z Bogiem i braćmi. Aby tak było, trzeba ciągle na nowo podejmować pastoralny wysiłek mistagogicznego przepowiadania o sakramencie pokuty i pojednania.

Słowa klucze: sakrament pokuty i pojednania; mistagogia liturgiczna; spowiedź.

Abstrakt. Sacrament of penance and reconciliation in the liturgical mystagogy. Polish Catholics in principle, they go to the sacrament of penance several times 
a year before important events, many of the faithful still confess every month before the first Friday. The problem is more or less, the regular approach to these sacraments. It is therefore sensible to look at the sacramental world of mercy from the perspective of its presence in the liturgical mystagogy exercised in the Church. The article reminds of the founding of modern liturgical mystagogy. Nevertheless, the main part is an attempt to bring the theological content closer to those that have been developed for the mercy, the ecclesial character of the liturgy of the discussed and its personal aspect. An important complement is to show that the sacrament of penance and reconciliation is always the celebration of the Church's liturgy.

Therefore, it shouldn't be something that someone believing in Christ should fear, but a mean enabling conciliating with God and brothers. For that to be it's necessary to constantly re-enter the pastoral effort of the mystagogical proclamation of the sacrament of penance and reconciliation.

Keywords: the sacrament of penance and reconciliation; liturgical mystagogy; confession.

Polscy katolicy zasadniczo przystępują do sakramentu pokuty kilka razy w roku przed ważnymi uroczystościami, sporo wiernych nadal spowiada się co miesiąc przed pierwszym piątkiem miesiąca. Spowiednicy mogliby sporo powiedzieć o mniej lub bardziej rutynowym traktowaniu tego sakramentu. Celowe więc wydaje się spojrzenie na sakrament Bożego miłosierdzia z perspektywy jego obecności w mistagogii liturgicznej sprawowanej w Kościele. Aby ten problem dobrze uchwycić, trzeba najpierw przypomnieć, czym jest mistagogia liturgiczna jako taka. Wydaje się bowiem, że nadal to pojęcie jest dla wielu duszpasterzy, a co dopiero dla wiernych, niejasne. Wypada zatem, żeby się nie rozwodzić, przywołać encyklopedyczne hasło opracowane przez lubelskiego liturgistę, który przypomina, że w starożytnym Kościele mistagogia stanowiła metodę wprowadzania neofitów w głębsze pojmowanie misteriów wiary, ich treści teologicznych i znaczenia dla życia chrześcijańskiego ${ }^{1}$. Widzimy tu dwojakie podejście; jedni wyjaśniali katechumenom obrzędy chrzcielne przed ich przyjęciem. Taką metodą posługiwali się między innymi św. Jan Chryzostom, Teodor z Mopsuestii i św. Augustyn. Z kolei św. Ambroży uważał, że nie należy wyjaśniać obrzędów przed ich przyjęciem, ponie-

${ }^{1}$ Cz. Krakowiak, Mistagogia, EK 12 (2008), k. 1260. 
waż światło misteriów lepiej przenika do wnętrza tych, którzy stykają się z nimi jakby z zaskoczenia, niż tych, których uprzedzono jakimś wyjaśnieniem $^{2}$. Zawsze katechezy mistagogiczne były widziane jako coś innego niż katechezy katechizmowe, albo homilie, będące interpretacją i wykładnią tekstu biblijnego. Katechezy mistagogiczne miały za zadanie wprowadzić jak najlepiej w istotę chrześcijaństwa, którą jest osobowe spotkanie Chrystusa. Ponieważ dzieje się to przede wszystkim w sakramentach, metoda mistagogii sprowadzała się do wyjaśnienia teologicznej wymowy stosowanych w liturgii znaków i symboli. W naszych czasach problem mistagogii pojawia się oficjalnie w księdze obrzędów chrześcijańskiego wtajemniczenia dorosłych ${ }^{3}$. Z wprowadzenia teologicznego i pastoralnego do tej księgi dowiadujemy się jedynie, że mistagogia (słowo zapisane w cudzysłowie) to okres pogłębionego wtajemniczania neofitów (nr 37), w którym powinni oni, przy pomocy rodziców chrzestnych, wejść w bardziej zażyłe związki z wiernymi, przekazać im świeże spojrzenie na sprawy wiary i dostarczyć nowych pobudek dla jej ożywienia (nr 39). O ile zatem mistagogia ma polegać na tym, że rodzice chrzestni pomagają neofitom wejść w pełni we wspólnotę wierzących, o tyle pewnym zaskoczeniem musi być druga część zacytowanego zdania. Wynika z niego, że mistagogia ma polegać także na tym, że to neofici mają przekazać wspólnocie świeże spojrzenie na sprawy wiary i dostarczyć jej nowych pobudek dla jej ożywienia. Wydaje się, że ten aspekt mistagogii jest zupełnie zarzucony. Nie widzi go też Katechizm Kościoła Katolickiego, który mistagogię (nadal w cudzysłowie) nazywa katechezą liturgiczną, mającą wprowadzić w misterium Chrystusa, przechodząc od tego, co widzialne, do tego, co niewidzialne, od znaku do tego, co on oznacza, od „sakramentów” do „misteriów” (nr 1075).

\section{ZAŁOŻENIA WSPÓŁCZESNEJ MISTAGOGIl LITURGICZNEJ}

Misterium liturgii, uobecniające paschalne dzieło Chrystusa, jest $\mathrm{w}$ istocie swojej wydarzeniem nadprzyrodzonym, ale też czymś, co jest tu

${ }^{2}$ H. J. Sobeczko, Rola i miejsce mistagogii w Kościele pierwotnym, w: A. Żądło (red.), Mistagogia a duchowość, Katowice 2004, s. 35.

3 Wersja dostosowana do zwyczajów diecezji polskich została wydana w Katowicach w $1988 \mathrm{r}$. 
i teraz uobecniane we wspólnocie ludzi wierzących. Zatem jako zjawisko społeczne podlega nieustannie zasadom aktualizacji do współczesnych realiów życia uczniów Jezusa. Duszpasterskim błędem byłoby więc akcentowanie znaczenia jedynie ceremonialnej, czyli rytualnej strony liturgii, bez wchodzenia w jej duchowy wymiar. Aby tak się nie stało, liturgia, rozumiana jako misterium wiary, ośrodek i źródło zbawienia, wymaga nieustannego wtajemniczania w rozumienie jej istoty i skutków. Miał więc rację św. papież Jan Paweł II, który - wydając ponad ćwierć wieku temu list apostolski o świętej liturgii, z okazji 25-lecia ogłoszenia Konstytucji Sacrosanctum concilium - wypowiedział się na ten temat. Napisał wtedy, że wiele należy jeszcze zrobić, by kapłanom i wiernym dopomóc w zgłębianiu obrzędów i tekstów liturgicznych. Dodał też, że powinno się to dokonywać w zainicjowaniu na wzór Ojców Kościoła katechezy mistagogicznej sakramentów ${ }^{4}$. Te wypowiedzi papieża pokazują, że znany był mu fakt, iż mistagogię liturgiczną wyróżnia spośród innych form chrześcijańskiego wychowania to, że pomaga ona człowiekowi w osobowym spotkaniu z Bogiem działającym w liturgii Kościoła. Dokonuje się ono najpierw poprzez właściwe przygotowanie do przyjęcia sakramentów świętych, by przez ich sprawowanie nastąpiło otwarcie się na Bożą łaskę. Kolejnym krokiem jest permanentna formacja sakramentalna dokonująca się przez lata. Te słowa papieża Polaka uwzględniały zapewne znaną mu z tamtych czasów kondycję Kościoła w Polsce. Musimy być jednak świadomi tego, że sytuacja ta znacząco się pogorszyła. Obecny w nasze religijnej rzeczywistości proces dechrystianizacji, odznaczający się indyferentyzmem religijnym i zmniejszaniem się liczby ludzi określających się jako ludzie wierzący, stanowi poważne wezwanie dla wszystkich zaangażowanych we współczesne duszpasterstwo, także to tzw. duszpasterstwo liturgiczne. Trzeba w tym miejscu zaznaczyć, że posoborowa odnowa liturgii została zrealizowana przez Kościół w Polsce w stopniu przynajmniej zadowalają$\mathrm{cym}^{5}$, a widać to głównie w płaszczyźnie rubrycystyczno-obrzędowej. Ale

${ }^{4}$ List apostolski Ojca św. Jana Pawła II $w$ dwudziesta piąta rocznice ogłoszenia Konstytucji soborowej „Sacrosanctum concilium” o świętej liturgii, Città del Vaticano 1988, nr 21.

${ }^{5}$ Szerzej na ten temat zob. E. Mateja, Die Einführung der nachkonziliaren liturgischen Bücher in Polen. Wprowadzenie posoborowych ksiąg liturgicznych w Polsce (Str.), w: K. Glombik, B. Kranemann (red.), Die Rezeption des Zweiten Vatikanischen Konzils. 
nie możemy stracić w pola widzenia faktu, że Kościół w Polsce był przez lata zamknięty w swej działalności jedynie w murach swoich świątyń i sal katechetycznych. Przyjęto bowiem fałszywą zasadę, pokutującą w wielu środowiskach po dzień dzisiejszy, że duszpasterstwo w Polsce jest masowe, czyli nastawione na tłumy wiernych. Rzecz jasna takie nastawienie wykluczało niemal z diecezjalnego i parafialnego duszpasterstwa formację indywidualną. Ks. biskup i ks. proboszcz był, i często nadal jest, nastawiony na bezimienny tłum, ale traci w tym momencie pojedynczego, czasem zagubionego, człowieka, który potrzebuje mistagogii. Masowe celebracje mają swoje religijno-społeczne znaczenie, ale nie mają większego wpływu na liturgiczną formację wiernych, którym odpowiada klimat wielkich spotkań. Ponieważ nie spotykają go potem w swoich kościołach parafialnych, gdzie liturgia sprawowana jest czasem zbyt pośpiesznie, a czasem z oznakami rutyny i znudzenia. Przekłada się to zatem na samą frekwencję, która nie napawa optymizmem. Dotyczy to zarówno dorosłych, jak i młodzieży oraz dzieci. Najnowsze dane statystyczne Instytutu Statystyki Kościoła Katolickiego SAC pokazują, co prawda, pewną stabilizację gdy chodzi o liczbę uczestników niedzielnych liturgii, ale prowadzący badania ks. Wojciech Sadłoń SAC zauważa, że sakramenty przyjmowane są w sposób masowy, niemal powszechny ${ }^{6}$. Należy więc postawić pytanie: jak wiele miejsca przewiduje dzisiejsza szkolna edukacja religijna dzieci i młodzieży na formację liturgiczną młodego pokolenia? Jak ten temat widzą ciągle zmieniane programy nauczania? Kolejnym problemem w tym zakresie są sami duszpasterze, którzy są odpowiedzialni za sprawowanie świętych misteriów i za mistagogię swoich dorosłych parafian. Sami powinni być przeniknięci duchem liturgii i przekonani, że warto inwestować czas i wysiłek w mistagogię liturgiczną współczesnych chrześcijan powierzonych ich trosce duszpasterskiej.

W tym miejscu przejdźmy zatem do istotnego problemu niniejszego przedłożenia, to znaczy do pokazania, że wielce pomocną metodą $\mathrm{w}$ formacji liturgicznej wiernych do owocnego korzystania $\mathrm{z}$ sakramentu

Erfahrungen der polnischen Volkskirche und der ost- und mitteldeutschen Diasporakirche / Recepcja Soboru Watykańskiego II. Doświadczenia Kościoła w Polsce i Kościoła diaspory wschodnich i centralnych Niemiec, „Colloquia Theologica” 14 (2011), s. 71-76.

${ }^{6}$ https://misericors.org/statystyki-kosciola-katolickiego-w-polsce-za-rok-2017prezentacja-raportu-iskk-8-stycznia-2019/ (data dostępu 14.03.2019). 
pokuty i pojednania może być przybliżanie im od czasu do czasu teologii liturgii tego sakramentu.

\section{TREŚCI TEOLOGICZNE ODNOWIONEJ LITURGII POKUTY I POJEDNANIA}

\subsection{BÓG JEST OJCEM MIŁOSIERDZIA}

Fundamentalną prawdą, jaką musi mieć przed oczyma każdy chrześcijanin korzystający z sakramentalnej pokuty, jest ta, która mówi, że wszechmogący Bóg jest nie tylko Bogiem miłosiernym, ale jest Ojcem miłosierdzia. We wprowadzeniu teologicznym i pastoralnym do księgi „Obrzędy pokuty dostosowane do zwyczajów diecezji polskich” czytamy, że grzesznik, który dzięki łasce miłosiernego Boga wchodzi na drogę pokuty, wraca do Ojca, który „pierwszy nas umiłował” (J 4,19) (Obrzędy pokuty, nr 5). Miłosierdzie Boga jest podkreślone już w obrzędzie przyjęcia penitenta. Istotna jest tu sama postawa kapłana, który powinien przyjąć pokutnika „z braterską miłością i ewentualnie niech go pozdrowi uprzejmymi słowami” (Obrzędy pokuty, nr 16). Sakrament pokuty musi być zawsze widziany w świetle tajemnicy pojednania obecnej w historii zbawienia. Zrozumiemy wtedy, że to Bóg pierwszy powziął w swoim miłosierdziu inicjatywę pojednania ze sobą grzesznej ludzkości: „W Chrystusie Bóg pojednał ze sobą świat, nie poczytując ludziom ich grzechów” (2 Kor 5, 19). O miłosiernym Bogu uczył sam Jezus w przypowieściach o pasterzu poszukującym zaginionej owcy $(Ł k 15,1-7)$ oraz o ojcu czekającym na marnotrawnego syna (Łk 15, 11-32). W naszej więc pracy formacyjnej trzeba prawdę o tym, że Bóg jest Bogiem miłosiernym, poszerzać, podkreślając, iż jest On równocześnie Ojcem miłosierdzia. Prawdę tę wyraża sam początek formuły rozgrzeszenia, gdy pojawiają się słowa: „Bóg, Ojciec miłosierdzia” (Obrzędy pokuty, nr 46). Warto o tym pamiętać zwłaszcza w naszych czasach, kiedy tak mocno rozwija się kult miłosierdzia Bożego za sprawą objawień św. s. Faustyny ${ }^{8}$. W tym miejscu trzeba zauważyć, że czasem o obrazach namalowanych według

7 Katowice 1981, dalej stosowany będzie skrót: Obrzędy pokuty.

8 J. Orchowski, Święta Siostra Faustyna i Boże Miłosierdzie, Nowy Sącz 2002, s. 48. 
jej wskazań mówi się, że są to obrazy Jezusa Miłosiernego. Tymczasem skoro Bóg jest nie tylko miłosierny, lecz także jest Ojcem miłosierdzia, to nie ma takiego miłosierdzia, które by nie pochodziło od Boga, gdyż każda forma autentycznego miłosierdzia ma swe źródło w Jego miłosierdziu.

\subsection{ROLA CHRYSTUSA W DZIELE BOŻEGO MIKOSIERDZIA}

Zacytowany wyżej fragment $\mathrm{z}$ drugiego listu św. Pawła do Koryntian przypomina nam, że Bóg pojednał nas ze sobą przez Chrystusa. Jest też mowa o tym w pierwszym zdaniu wprowadzenia teologicznego i pastoralnego, gdzie czytamy: „Bóg Ojciec okazał swoje miłosierdzie przez Chrystusa, jednając z sobą wszystko, co jest na ziemi i co jest w niebie, przywracając pokój przez Jego krew przelaną na krzyżu” (Obrzędy pokuty, nr 1). Obrzędy przewidują wyrażenie tej prawdy w jednej z propozycji modlitwy penitenta przed rozgrzeszeniem. Może on bowiem wyrazić swój żal słowami „Boże mój [...] przez zasługi męki Jezusa Chrystusa zmiłuj się nade mną” (Obrzędy pokuty, nr $45 \mathrm{c}$ ). Ta sama myśl pojawia się w samej formule rozgrzeszenia, kiedy padają słowa: „Bóg, Ojciec miłosierdzia, który pojednał świat ze sobą przez śmierć i zmartwychwstanie swojego Syna" (Obrzędy pokuty, nr 46). Penitent powinien zatem wiedzieć, że to misterium paschalne uobecniane nieustannie $\mathrm{w}$ liturgii, odgrywa zasadniczą rolę $\mathrm{w}$ procesie pojednania człowieka z Bogiem. To właśnie dzięki śmierci i zmartwychwstaniu Chrystusa dzieje każdego człowieka, mimo jego upadków, nie są beznadziejne. Przeciwnie, dzięki Chrystusowi i Jego ofierze są pełne nadziei i optymizmu. Bo to miłosiernemu sądowi Chrystusa penitent oddaje swoje, grzechami obarczone, sumienie i doznaje odrodzenia, odnowienia, umocnienia życia łaski, godności dziecka Bożego i dziedzica chwały niebieskiej.

\subsection{ROLA DUCHA ŚWIĘTEGO W DZIELE BOŻEGO MIŁOSIERDZIA}

Każdy penitent musi wiedzieć, że wierzymy w jednego Boga, który się objawił w Trójcy Świętej, a zatem trzeba też pamiętać o Duchu

9 W. Schenk, Liturgia sakramentów świętych. Część II. Paenitentia christina, pokuta i chorych namaszczenie, consecratio mundi, kapłaństwo i małżeństwo, Lublin 1964, s. 46. 
Świętym i Jego roli w procesie pojednania się człowieka z Bogiem. Rola ta zostaje wyraźnie określona $\mathrm{w}$ formule rozgrzeszenia, gdzie jest mowa o tym, że Bóg zesłał Ducha Świętego na odpuszczenie grzechów (por. Obrzędy pokuty, nr 46). Działanie Ducha Świętego widoczne jest już wtedy, gdy penitent decyduje się na przystąpienie do sakramentu pokuty. Wtedy Trzecia Osoba Trójcy Świętej udziela grzesznikowi potrzebnego światła, dzięki któremu poznaje zło swoich grzechów i podejmuje wysiłek kształcenia swego sumienia ${ }^{10}$. Zdobywa się następnie na akt żalu za popełnione grzechy i decyduje się na podjęcie postanowienia poprawy. To prowadzi go do spowiedzi, w której wyznaje nie tylko grzechy ciężkie, ale i powszednie, mając świadomość tego, że każdy grzech jest raną zadaną Kościołowi, który, będąc Ciałem Chrystusa, jest Świątynią Ducha Świętego. Przez sakrament pokuty „Duch Święty na nowo uświęca swoją świątynię albo pełniej w niej zamieszkuje" (Obrzędy pokuty, nr 6 d). To zdanie podkreśla podwójną rolę Ducha Świętego, który w przypadku popełnienia przez człowieka grzechów śmiertelnych na nowo go uświęca, a w sytuacji spowiedzi z grzechów powszednich wypełnia serce człowieka w sposób pełniejszy. Nie wolno też zapominać o obecności Ducha Świętego w szafarzu sakramentu. Mając natomiast na uwadze to, czym jest liturgia, że w sakramencie pokuty Bóg przez Chrystusa w Duchu Świętym uświęca grzesznika, a pojednany w ten sposób człowiek w tymże Duchu Świętym oddaje przez Chrystusa Bogu Ojcu należny kult, uwielbienie, cześć i chwałę ${ }^{11}$.

\subsection{EKLEZJALNY WYMIAR LITURGII SAKRAMENTU POKUTY 1 POJEDNANIA}

Drugi rozdział wprowadzenia do Obrzędów pokuty otrzymał tytuł: „Pojednanie penitentów w życiu Kościoła”. Natomiast pierwszy podtytuł brzmi: „Kościół święty a zarazem zawsze potrzebujący oczyszczenia”. Jest to sformułowanie zapożyczone z Konstytucji Lumen gentium (por. KK 8).

${ }^{10}$ A. Skowronek, Z teologicznej problematyki pokuty, w: A. Skowronek, S. Czerwik, M. Czajkowski (red.), Sakrament pokuty. Teologia, liturgia, Pismo Św., Katowice 1980, s. 107.

11 W. Świerzawski, Dialektyczny dynamizm sakramentów pokuty i Eucharystii, RBL 39 (1976), nr 2-3, s. 115. 
Trzeba w tym miejscu zaznaczyć, że soborowa eklezjologia miała mocny wpływ na odnowę liturgii ${ }^{12}$, także tej, która związana jest z sakramentem pokuty i pojednania, jak i na samo pojmowanie pokuty. Jest ona czymś, co towarzyszy Kościołowi nieustannie. Tak samo powinno być w życiu każdego chrześcijanina, którego oczyszczanie powinno przybierać różne formy. Wylicza je nr 4 wprowadzenia. Są to: a) cierpliwe uczestniczenie w cierpieniach Chrystusa, b) wypełnianie dzieł miłosierdzia i miłości, c) codzienne nawracanie się zgodnie z wymaganiami Ewangelii. Jednocześnie trzeba pamiętać, że wszystko to znajduje się też w liturgii Kościoła wtedy, gdy wierni uznają, że są grzesznikami i proszą Boga i braci o przebaczenie $\mathrm{w}$ trakcie nabożeństw pokutnych, gdy głosi się słowo Boże, a także w modlitwie, zwłaszcza w pokutnych elementach liturgii eucharystycznej. Dopiero na tak zarysowanym tle trzeba widzieć sam sakrament pokuty, który stanowi kulminację pokutnej liturgii Kościoła. To w nim bowiem wierni „otrzymują od miłosierdzia Bożego przebaczenia zniewagi wyrządzonej Bogu i jednocześnie jednają się z Kościołem, któremu grzesząc zadali ranę, a który przyczynia się do ich nawrócenia miłością, przykładem i modlitwą" (por. KK 11).

Na ten eklezjalny wymiar pokuty wskazuje kolejny numer wprowadzenia do księgi, który mówi o tym, że ludzie często działają wspólnie, popełniając niesprawiedliwość. Podobnie powinno być w obszarze pokuty, gdzie konieczne jest, by wierni wspomagali się wzajemnie i uwolnieni od grzechu współdziałali z ludźmi dobrej woli celem krzewienia w świecie sprawiedliwości i pokoju (por. Obrzędy pokuty, nr 5). Warto w naszych czasach przypominać, że liturgia pokuty miała pierwotnie bardziej czytelną formę społeczną. Grzesznik odbywał bowiem pokutę w obliczu wspólnoty, zadośćuczynił nie tylko Bogu, a i społeczności wiernych. $\mathrm{Z}$ kolei gmina prosiła Boga o odpuszczenie mu grzechów, modląc się za niego i czując się współodpowiedzialnym za grzech brata. Także samo rozgrzeszenie pokutnika zawsze miało charakter społeczny ${ }^{13}$. Odpuszczenie grzechów jest bowiem dziełem Boga i Kościoła.

12 A. Gerhards, Stationen der Gottesbegegnung. Zur theologischen Bestimmung der Sakramentenfeiern, w: M. Klökener, W Glade (red.), Die Feier der Sakramente in der Gemeinde, Kevelaer 1986, s. 20.

${ }^{13}$ B. Poschmann, Paenitentia secunda. Die kirchliche Buse im ältesten Christentum bis Cyprian und Origines, Bonn 1940, s. 266. 
Co prawda, zmiana zewnętrznych form pokuty wprowadzona za sprawą misjonarzy iroszkockich przysłoniła w świadomości wiernych fakt, że grzech i pokuta nie są tylko sprawą pojedynczego człowieka, ale mają nadal charakter społeczny. Fakt eklezjalnego wymiaru grzechu i podjętej pokuty, a przede wszystkim udzielenie rozgrzeszenia i przyjęcie pokutnika do wspólnoty nie uległ żadnej zmianie. Dlatego powinien być nadal obecny w naszym przepowiadaniu mistagogicznym.

Warto też pamiętać, że posoborowa księga zawierająca obrzędy pokuty zaakcentowała eklezjalny wymiar grzechu i pojednania proponując, jako nowość, drugą i trzecią formę sprawowania sakramentu pokuty polegającą na wspólnym przygotowaniu wielu penitentów do indywidualnej spowiedzi przez wspólny śpiew, rozważanie słowa Bożego, rachunek sumienia, wspólną modlitwę oraz wspólne dziękczynienie po spowiedzi. W komentarzach do tych form pokuty podkreśla się, że ich uczestnicy mają szansę zrozumieć, iż nawrócenie i pokuta nie jest tylko czymś, co się rozgrywa miedzy Bogiem a grzesznikiem ${ }^{14}$. We wprowadzeniu do księgi czytamy, że takie wspólne nabożeństwo jaśniej ukazuje kościelną naturę pokuty (Obrzędy pokuty, nr 22). Trzeba w tym miejscu postawić pytanie: $\mathrm{w}$ jakim stopniu obecny jest w naszym duszpasterstwie obrzęd pojednania wielu penitentów $\mathrm{z}$ indywidualną spowiedzią i rozgrzeszeniem? Wydaje się, że tego typu celebracje, znane klerykom z praktyk seminaryjnych, rzadko są stosowane w duszpasterstwie parafialnym.

W interesującym nas kontekście eklezjalnym pokuty i pojednania trzeba tė̇ pamiętać, że posoborowa księga dowartościowała też same nabożeństwa pokutne, rozumiane jako gromadzenie ludu Bożego na słuchanie słowa Bożego, przez które otrzymuje wezwanie do nawrócenia i odnowy życia oraz wieść o naszym wyzwoleniu z grzechu przez śmierć i zmartwychwstanie Chrystusa (Obrzędy pokuty, nr 36). Nabożeństwa takie mają za zadanie rozwijać ducha pokuty w społeczności chrześcijańskiej i przygotować wiernych do spowiedzi, którą mają odbyć później indywidualnie $\mathrm{w}$ dogodnym czasie. W przypadku dzieci nabożeństwa takie mają je wychowywać do stopniowego uświadomienia sobie, czym jest grzech w życiu ludzi i wyzwolenie z niego przez Chrystusa. Z kolei

${ }^{14}$ K. Richter, Was die sakramentalen Zeichen bedeuten. Zu Fragen aus der Gemeinde heute, Freiburg im Breisgau 1988, s. 88. 
katechumenom mają one pomóc w nawróceniu (Obrzędy pokuty, nr 37). Rytuał zawiera też $\mathrm{w}$ drugim dodatku nabożeństwa pokutne na okres wielkiego postu i adwentu. W pierwszym przypadku mają one pomóc podjąć pokutę i przygotować się do owocniejszego udziału w świętowaniu paschy Chrystusa (nr 7), a w okresie adwentu mają na celu przygotowanie wiernych do uroczystego obchodzenia tajemnicy wcielenia Chrystusa oraz pobudzać do oczekiwania na drugie przyjście Pana (por. nr 20).

Celebrując takie nabożeństwa, trzeba wiernych jasno informować o ich formacyjnym znaczeniu. Trzeba czuwać, aby nabożeństwa pokutne $\mathrm{w}$ przekonaniu wiernych nie identyfikowały się ze sprawowaniem sakramentu pokuty (Obrzędy pokuty, nr 37). Tej troski zabrakło w wielu parafiach na zachodzie Europy, gdzie błogosławieństwo prezbitera albo stałego diakona udzielane na końcu nabożeństwa traktowane jest przez wiernych jako rozgrzeszenie. Efektem jest nieprzystępowanie przez nich do spowiedzi z indywidualnym rozgrzeszeniem.

Do całości obrazu trzeba też dodać, że wierni powinni dowiedzieć się także, iż omawiana księga liturgiczna zawiera w trzecim rozdziale obrzęd pojednania wielu penitentów z ogólną spowiedzią i rozgrzeszeniem (Obrzędy pokuty, nr 61-68) ${ }^{15}$. W polskich warunkach nie ma jednak potrzeby stosowania go, ponieważ każdy wierny przy dobrej woli może korzystać z łaski pojednania przez spowiedź indywidualną (Obrzędy pokuty, nr $38^{\star}$ e).

\subsection{PERSONALISTYCZNY WYMIAR LITURGII SAKRAMENTU POKUTY I POJEDNANIA}

Przedstawiony wyżej eklezjalny charakter interesującego nas sakramentu w niczym nie przekreśla ani nie pomniejsza znaczenia osoby grzesznika i tego, co jest jego osobistym wysiłkiem w procesie nawrócenia. W sakramencie pokuty jest bowiem wiele miejsca na w pełni ludzkie działanie każdego grzesznika. O ile bowiem chrzest jest odpuszczeniem

${ }_{15}$ Szerzej na temat tego obrzędu zob. D. Kwiatkowski, Obrzęd pojednania wielu penitentów z ogólną spowiedzią i rozgrzeszeniem, w: M. Olczyk, W. Radecki, (red.), Memoriale Domini. Ksiega pamiątkowa dedykowana księdzu profesorowi Jerzemu Stefańskiemu w 70. Rocznice urodzin, Gniezno 2010, s. 233-257. 
grzechów z Bożej łaski na prośbę danej osoby lub w przypadku dziecka jego rodziców, o tyle w przypadku sakramentu pokuty osobisty wysiłek penitenta należy do istotnej materii sakramentu. Nie jest więc on tylko biernym odbiorcą łaski sakramentu, ale tym, który aktywnie przyczynia się do jej zaistnienia. Bez jego czynnego udziału nie możemy mówić o liturgii tego sakramentu. Posoborowa odnowa liturgii miała bowiem przygotować członków Kościoła do świadomego i czynnego w niej uczestnictwa ${ }^{16}$. W Kościele pierwszych wieków zaangażowanie penitenta było bardzo widoczne. Nosił on specjalny ubiór pokutnika, pościł, odmawiał modlitwy, leżąc krzyżem i wykonywał liczne uczynki miłości dla swojej wspólnoty i jej członków ${ }^{17}$. Dopiero kiedy stwierdzano, że tych działań pokutnych jest wystarczająco dużo, udzielano mu rozgrzeszenia i przyjmowano do pełnej jedności ze wspólnotą. Dziś liturgia tego sakramentu jest zdecydowanie prostsza, ale to w niczym nie pomniejsza wagi osobistego udziału w niej penitenta. Należy zatem podkreślać w naszym przepowiadaniu mistagogicznym, że brak autentycznego zaangażowania grzesznika w liturgii sprawi, iż będzie to obrzęd bez treści, a co za tym idzie, może to być obrzęd bez sakramentalnej skuteczności, gdyż udział penitenta należy do istoty sakramentu. Problem zaczyna się już w podejściu do rachunku sumienia, bowiem jeśli wierny będzie się w tym miejscu ograniczał tylko do policzenia wszystkich grzechów popełnionych od ostatniej spowiedzi, ażeby za nie żałować i wyznać kapłanowi, sumieniu jemu grozić może straszliwy uwiąd i skarłowacenie: będzie dreptał wokół częściowego, negatywnego aspektu swego życia wewnętrznego ${ }^{18}$.

Zanim więc grzesznik skupi uwagę na czynach wyrażających jego pokutę, musi pamiętać, że wezwanie Chrystusa do nawrócenia i pokuty odnosi się najpierw do nawrócenia wewnętrznego. To od skruchy serca zależy prawdziwość pokuty. Wprowadzenie do obrzędów przypomina, że wewnętrzne nawrócenie serca, zawierające żal za grzechy i postanowienie nowego życia, wyraża się przez wyznanie grzechów wobec Kościoła, przez należyte zadośćuczynienie i poprawę życia (Obrzędy pokuty, nr 6). Tak

${ }^{16}$ S. Czerwik, Wprowadzenie do odnowionej liturgii pokuty i pojednania, w: A. Skowronek, S. Czerwik, M. Czajkowski (red.), Sakrament pokuty. Teologia, liturgia, Pismo Św., Katowice 1980, s. 176.

17 Tamże, s. 147.

18 A. Skowronek, Z teologicznej problematyki pokuty, s. 107. 
więc pierwszym i jednocześnie najważniejszym aktem penitenta jest żal za grzechy, który powinien wypływać z miłości do Boga miłowanego nade wszystko, a nie tylko z lęku przed Bożą karą. Katechizm Kościoła Katolickiego dodaje potrzebę poprzedzenia sakramentu pokuty rachunkiem sumienia (nr 1454). Można go przeprowadzić w oparciu o Boże przykazania, o osiem błogosławieństw, uczynki miłości Boga, bliźniego i siebie samego. Trzeba też uwzględniać grzechy kontekstualne, będące owocem marnowania talentów, złego podchodzenia do pracy i zachowania przepisów cywilnych, czy troski o potrzebujących. Przeprowadzenie dobrego rachunku sumienia wymaga czasu. Trzeba to podkreślać po to, by zwłaszcza częste spowiedzi nie stawały się czysto obrzędowym powtarzaniem tego samego lub nie szły w kierunku rozmowy psychoanalitycznej kończącej się rozgrzeszeniem.

Zewnętrznym wyrazem żalu za grzechy jest wyznanie grzechów, będące swoistym jawnym sądem, któremu grzesznik się poddaje, oskarżając samego siebie. Taki akt dokonany przed kapłanem jest czytelnym uznaniem społecznego charakteru grzechu i pokuty. Poważnym problemem jest sam sposób wyznania grzechów. Dobrze by było, gdyby dokonało się odejście od szablonowych, utartych, a czasem wręcz dziecinnych formuł na rzecz bardziej osobistej wypowiedzi, w której będzie też miejsce na podanie genezy grzechów. Tak rozumiana spowiedź domaga się od penitenta pełnego otwarcia serca przed spowiednikiem. Aby wierny mógł przyjąć zbawienne działanie sakramentu pokuty, zgodnie z wolą miłosiernego Boga, powinien wyznać szczegółowo wszystkie grzechy ciężkie, które sobie przypomina po zbadaniu sumienia (Obrzędy pokuty, nr 7a). Nie powinien mieć w tym żadnych obaw, że coś wstydliwego z jego życia wyjdzie na jaw, bo musi on wiedzieć, że każdy kapłan, który spowiada, zobowiązany jest pod bardzo surowymi karami do zachowania absolutnej tajemnicy odnośnie do grzechów wyznanych przez penitentów (KKK 1467).

Żal za grzechy i ich wyznanie nie mogą być niczym zastąpione. Jako szczere akty pokutnika powinny zaowocować poprawą życia oraz naprawieniem wyrządzonych krzywd i adekwatnym do grzechów zadośćuczynieniem. Warto w tym miejscu zauważyć, że we wprowadzeniu do obrzędów pokuty stawia się zadośćuczynienie przed rozgrzeszeniem (por. Obrzędy pokuty, nr 6 c,d). Rodzi się pytanie: czy jest to tylko nawiązanie do praktyki znanej w przypadkach pokuty publicznej, albo jest to 
wskazanie na możliwość zachowania takiej kolejności dzisiaj w pewnych szczególnych przypadkach, w których naprawienie wyrządzonych krzywd i zadośćuczynienie powinno poprzedzać końcowe rozgrzeszenie? Współczesna praktyka tzw. łatwej pokuty sprowadzającej się do zadośćuczynienia $\mathrm{w}$ formie modlitwy nie uświadamia penitentowi, że jest pokutnikiem ${ }^{19}$. Trzeba się pytać, czy dobrą praktyką jest zalecanie tylko modlitewnych form zadośćuczynienia z pominięciem pokuty wyrażającej się konkretnymi czynami. Wydaje się, że brak proporcji pomiędzy grzechem a nałożoną pokutą relatywizuje u penitenta wagę grzechu i nie budzi ducha prawdziwego zadośćuczynienia. A przecież zadośćuczynienie wyrażone w czynie jest swoistym sprawdzianem autentyczności żalu osoby przystępującej do sakramentu pokuty i pojednania. Istotą zadośćuczynienia ma być naprawienie krzywdy wyrządzonej Bogu i bliźniemu. W pierwszym przypadku może to być poświęcenie Bogu czasu przez lekturę Biblii, modlitwę, uczestnictwo we Mszy w dzień powszedni czy udział w adoracji Najświętszego Sakramentu. W przypadku bliźniego musi to być zawsze restytucja sławy i mienia, jeśli miały miejsce grzechy w tej materii. Wskazane jest też słowo przeproszenia do tych, których dotknęło nasze złe zachowanie, słownictwo czy myślenie. Zadośćuczynienie ma zawsze dążyć do przywrócenia porządku moralnego zaburzonego przez najmniejszy nawet grzech. Ma też być nie tylko ekspiacją za popełnione grzechy, lecz również wstępem do rozpoczęcia nowego, lepszego stylu życia. Zatem ma mieć też charakter leczący ${ }^{20}$.

\section{SAKRAMENT POKUTY I POJEDNANIA JEST SPRAWOWANIEM LITURGII KOŚCIOŁA}

Na ten mało obecny w świadomości wiernych aspekt zwraca uwagę wprowadzenie do obrzędów, kiedy mówi, że wierny doświadczając w swoim życiu miłosierdzia Bożego i głosząc je, sprawuje razem z kapłanem liturgię Kościoła, który nieustannie się odnawia (Obrzędy pokuty, nr 11).

19 W. Schenk, Liturgia sakramentów świętych, s. 51.

${ }^{20}$ H. J. Sobeczko, Sakrament pokuty i pojednania w nowym Katechizmie Kościoła Katolickiego, w: J. J. Kopeć, H. Sobeczko, R. Pierskała (red.), Misterium liturgii w Katechizmie Kościoła Katolickiego, Opole 1995, (seria Sympozja nr 8), s. 110. 
W kolejnych punktach wprowadzenia pojawia się problem czasu sprawowania tego sakramentu, temat od lat kontrowersyjny. Pewne jest, że czas ten powinien być wiernym znany, a zatem ustalony w sposób trwały. Uprzywilejowanym czasem sprawowania sakramentu pokuty i pojednania jest okres wielkiego postu. Dlatego zaleca się urządzanie w tym czasie nabożeństw pokutnych oraz dawanie wiernym możliwości pojednania się z Bogiem i braćmi, aby z odnowionym sercem mogli przeżywać tajemnicę paschalną (Obrzędy pokuty, nr 13). O ile ten postulat jest w naszej rzeczywistości parafialnej zasadniczo poprawnie realizowany, o tyle zalecenie, by wiernych przyzwyczajać do spowiadania się poza sprawowaniem Mszy św. (por. Obrzędy pokuty, nr 13), pozostawia nadal wiele do życzenia. W spojrzeniu na ten problem trzeba najpierw rozróżnić posługę księży $\mathrm{w}$ konfesjonale $\mathrm{w}$ dni powszednie oraz $\mathrm{w}$ niedziele i święta. Jasną rzeczą jest, że gdy chodzi o dni powszednie i święta, w które nie ma obowiązku uczestniczenia we Mszy św., wierni mogą korzystać swobodnie z posługi spowiedników także w czasie celebracji Mszy św. Natomiast usilnie zaleca się, aby celebracja tego sakramentu nie pokrywała się z czasem i miejscem sprawowania Mszy św., zwłaszcza w niedziele i obowiązujące święta. Wynika więc z przepisów Kościoła, że spowiadanie w czasie niedzielnych i świątecznych Mszy św. jakkolwiek jest dopuszczalne, to jednak nigdy nie jest i nie będzie ideałem poprawnego duszpasterstwa. Idealnym rozwiązaniem są na stałe wyznaczone i podane do wiadomości wiernym dni i godziny, kiedy kapłani pełnią posługę w konfesjonale poza Mszą św.

Człowiek, stając się chrześcijaninem w momencie przyjęcia chrztu, wchodzi jednocześnie na drogę takiego formowania siebie, by - zgodnie z zaleceniem Chrystusa - być doskonałym jak Ojciec niebieski (por. Mt $5,48)$. W tej pracy nad sobą powinien więc chętnie i owocnie korzystać z sakramentu pokuty i pojednania. Ma on być dla niego nie czymś czego trzeba się bać, ale środkiem umożliwiającym jednanie się z Bogiem i braćmi. Aby tak było, trzeba ciągle na nowo podejmować pastoralny wysiłek mistagogicznego przepowiadania o sakramencie pokuty i pojednania. Otwierają się tu zarówno przed duchownymi, jak i wiernymi ciągle nowe perspektywy objawiania i urzeczywistniania duchowego bogactwa Bożego miłosierdzia powierzonego Kościołowi. 


\section{BIBLIOGRAFIA}

Obrzędy pokuty dostosowane do zwyczajów diecezji polskich, Katowice 1981.

Obrzędy chrześcijańskiego wtajemniczenia dorosłych dostosowane do zwyczajów diecezji polskich, Katowice 1988.

List apostolski Ojca św. Jana Pawła II $w$ dwudziestą piąta rocznicę ogłoszenia Konstytucji soborowej „Sacrosanctum concilium” o świętej liturgii, Città del Vaticano 1988.

Czerwik S., Wprowadzenie do odnowionej liturgii pokuty i pojednania, w: A. Skowronek, S. Czerwik, M. Czajkowski (red.), Sakrament pokuty. Teologia, liturgia, Pismo Św. Katowice 1980, s. 125-205.

Gerhards A., Stationen der Gottesbegegnung. Zur theologischen Bestimmung der Sakramentenfeiern, w: M. Klökener, W. Glade (red.), Die Feier der Sakramente in der Gemeinde, Kevelaer 1986, s. 17-30.

Krakowiak Cz., Mistagogia, EK 12 (2008), k. 1260-1262.

Kwiatkowski D., Obrzęd pojednania wielu penitentów z ogólną spowiedzią i rozgrzeszeniem, w: M. Olczyk, W. Radecki, (red.), Memoriale Domini. Księga pamiątkowa dedykowana księdzu profesorowi Jerzemu Stefańskiemu w 70. Rocznice urodzin, Gniezno 2010, s. 233-257.

Mateja E., Die Einführung der nachkonziliaren liturgischen Bücher in Polen. Wprowadzenie posoborowych ksiag liturgicznych w Polsce (Str.), w: K. Glombik, B. Kranemann (red.), Die Rezeption des Zweiten Vatikanischen Konzils. Erfahrungen der polnischen Volkskirche und der ost- und mitteldeutschen Diasporakirche / Recepcja Soboru Watykańskiego II. Doświadczenia Kościoła w Polsce i Kościoła diaspory wschodnich i centralnych Niemiec, „Colloquia Theologica” 14 (2011), s. 71-76.

Orchowski J., Święta Siostra Faustyna i Boże Miłosierdzie, Nowy Sącz 2002.

Poschmann B., Paenitentia secunda. Die kirchliche Buse im ältesten Christentum bis Cyprian und Origines, Bonn 1940.

Richter K., Was die sakramentalen Zeichen bedeuten. Zu Fragen aus der Gemeinde heute, Freiburg im Breisgau 1988.

Schenk W., Liturgia sakramentów świętych. Część II. Paenitentia christina, pokuta i chorych namaszczenie, consecratio mundi, kapłaństwo i małżeństwo, Lublin 1964.

Skowronek A., Z teologicznej problematyki pokuty, w: A. Skowronek, S. Czerwik, M. Czajkowski (red.), Sakrament pokuty. Teologia, liturgia, Pismo Św., Katowice 1980, s. 7-124.

Sobeczko H. J., Rola i miejsce mistagogii w Kościele pierwotnym, w: A. Żądło (red.), Mistagogia a duchowość, Katowice 2004, s. 30-45.

Sobeczko H. J., Sakrament pokuty i pojednania $w$ nowym Katechizmie Kościoła Katolickiego, w: J. J. Kopeć, H. Sobeczko, R. Pierskała (red.), Misterium liturgii w Katechizmie Kościoła Katolickiego, Opole 1995, (seria: Sympozja, nr 8), s. 101-112.

Świerzawski W., Dialektyczny dynamizm sakramentów pokuty i Eucharystii, RBL 39 (1976), nr 2-3, s. 106-116. 